\title{
Single-store Operations Manual: The Reproduction Method of Franchising System Service Products - On the Content of Single-store Operations Manual Written in Principle
}

\author{
Yuanmeng SHI \\ School of Franchising \\ Beijing Normal University (Zhuhai Campus) \\ Zhuhai ,Guangdong 519087,China
}

\author{
Dong YUAN \\ School of Franchising \\ Beijing Normal University (Zhuhai Campus) \\ Zhuhai ,Guangdong 519087, China
}

\begin{abstract}
-single-store operations manual has an important role in franchising. However, the nature of the single-store operations manual has been a lack of research, and therefore the lack of clear principles is on how to write a single store operations manual. Franchise Services products distributor that franchisees undertake a dual function: sales and service of products and service offerings reproduction. Therefore, the franchisor to the franchisee needs to provide a method of reproduction, single-store operations manual service product is the franchisor of their service production methods described in the text. Constitute a single store, including tangible evidence, service system and service standards. Therefore, these three aspects of the preparation of the contents constitute a single store operation manual.
\end{abstract}

Keywords- Single-store Operations Manual; Franchisee Reproduction Function; Single Store Constituents; Manual Writing Content

\section{INTRODUCTION}

Since the early 90s of last century, the franchising was entering the country, after 20 years of development; China has become the world's largest franchise system of the country. This paper attempts on the nature of the franchise system in a single store operations manual were analyzed, and the principle of single-store operations manual writing content is on this basis.

First, the service cannot be stored on the scale of the challenge of products sold

Service is an activity or interest (Philip kotler), rather than material, therefore, intangibility is the most obvious characteristics of products and services, but also service products and tangible products have essential difference. Services, in addition to this basic feature are intangible, but it also has not been stored. It refers to the so-called non-store inventory of service products that cannot be true. Inventory and tangible products are different on a day to continue to sell and service the product that can be used in the original, if not promptly produced to sell it cannot be stored until a later sale.

When the global economy goes towards a service economy from the beginning of the industrial economy, service offerings increasingly occupies an increasingly important position in the product structure. Similarly, for an excellent service product, there is demand for large-scale production and scale on the market, but the nature of the services cannot be stored product sales to large-scale challenge. If the service product manufacturers cannot be a large number of service products after the production, storage transported to other markets in the hands of distributors, local dealers can take what sold to local consumers.

Second, The Role and Functions of Franchisee of the Franchise System

\section{ACHIEVE LARGE-SCALE COMMERCIAL FRANCHISE SALES SERVICE PRODUCTS}

Business Franchising means that it has registered trademarks, corporate logos, patents, proprietary technology and other business resources of the enterprise. That is the franchisor, through the conclusion of the contract, which is owned by the management resources to permit other operators that is being used franchisor, is franchisor accordance with the contract to carry out business in a unified business model, pays the appropriate fee to the franchisor's business activities.

Whether it is the Chinese government or international organization on each franchise, they do belong to the definition of franchising descriptive definition, the definition of the typical characteristics of franchising activities will have to be a narrative. In fact, we see that it is franchising realized the scale of sales and service products through franchise services to meet the needs of certain products on the local markets. Therefore, business franchise is the product of large-scale service sales.

\section{THE ROLE AND FUNCTIONS OF THE FRANCHISEE IN THE FRANCHISE SYSTEM}

Franchising is a business service products to achieve large-scale sales of the way, the franchise system of two bodies are called the franchisor and franchisee or franchisee, that franchise is the franchisor and franchisee relationship forged product distribution services the division of labor relations. Therefore, joining the franchise relationship's role is to service products distributors.

In fact, because of tangible products and service offerings have fundamentally different characteristics of intangibility, 
leading to the realization of large-scale sales service product distribution process and implementation of various largescale sales of tangible goods distribution process, and therefore, it will service the product size oriented sales approach called special franchise dealer that will service products specially called franchisees. Although the franchise relationship, the franchisee still play the role of distributor, but its commitment to the functions and tangible product that is different compared to the dealer. Tangible products assume the functions of the main distributor sales, which is about tangible product manufacturers produced products sold to local consumers. Franchisee will assume a twofold function, first reproduction, followed by the sale. This is because the non-storage characteristics of service products enable service production functions in a foreign market, dealers need it to bear, when the dealer will service products reproduce it, and he began to perform the functions of a traditional sale. Such differences shown below:

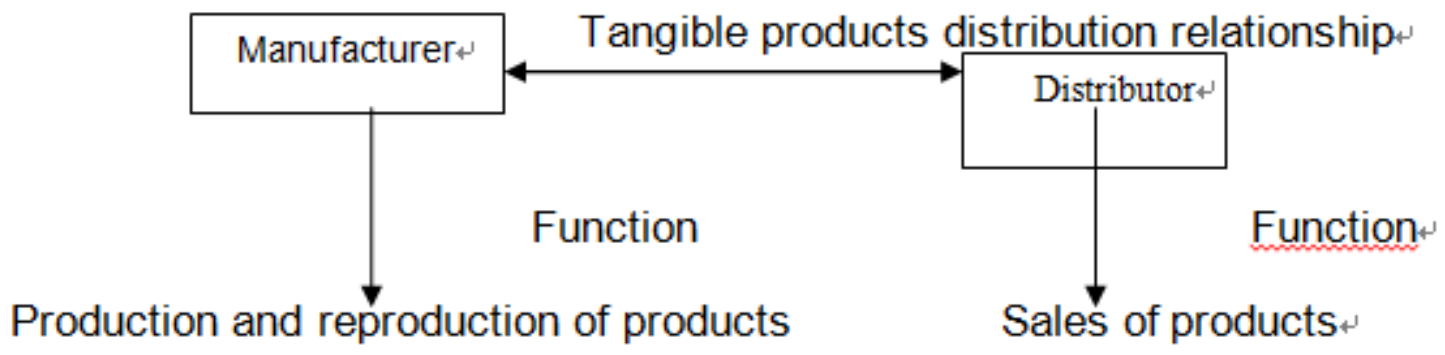

Figure 1 producer and distributor of functions

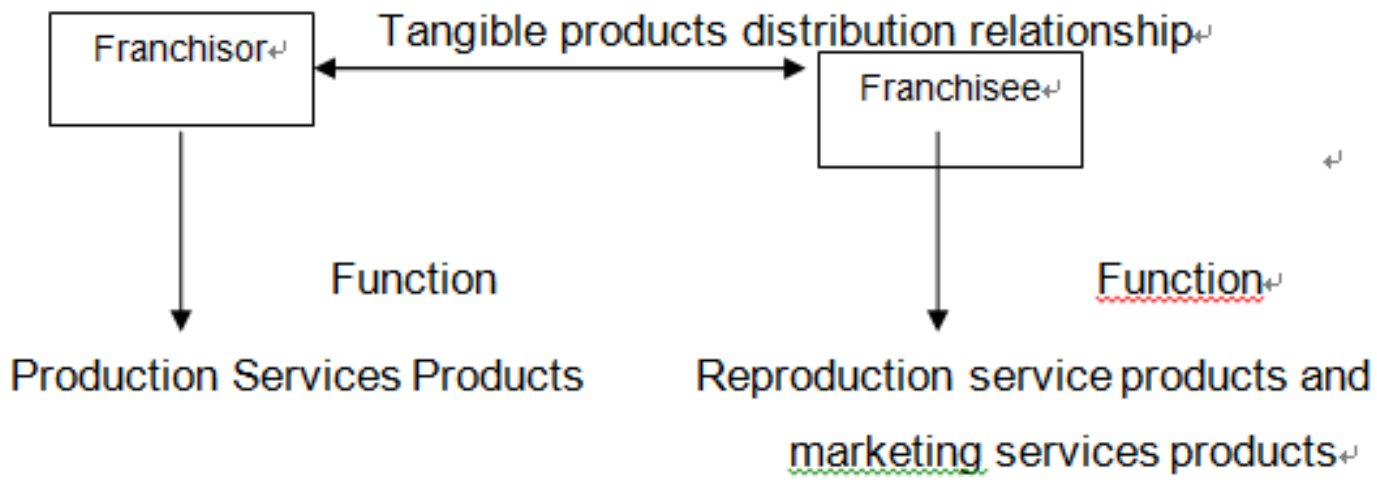

Figure 2 franchisor and franchisee functions

\section{THE NATURE OF OPERATIONS MANUAL AND CONTENT OF WRITTEN PRINCIPLE SINGLE-STORE}

\section{A. Properties of single-store operations manual}

Since in the large-scale sales and service of the product, service offerings reproduction is provided by the manufacturer (franchisor) outside members (franchisees), and it requires the franchisee to grasp the method of reproduction services products. In order to ensure the franchise system in different consistency or stability of franchisee's production services product quality, these different franchisees need to follow a uniform approach to the production of goods reproduction. This requires service products manufacturer (franchisor) that will be producing its own product development services for text extraction and summary to form a standard text readable for everyone to understand that this standard text is single-store operations manual. Therefore, the so-called single-store operations manual is about the franchisor's service reproduction method.

\section{B. A single store and its components}

1) Meaning of a single store

Tangible product is an entity, it must rely on the production process of these elements in all or part of plant, machinery and equipment, work force, production procedures, the final product can be produced with tangible carrier that depends on the composition of these elements 
together, we generally call factory. Services are intangible products, though it is the performance of a process. But let consumers ultimately feel the service, the service production process still need rely on these elements premises, equipment, labor, services, programs, etc.. All parts of the final product to service produced depend on the carrier composition of these elements together, we have many names, such as convenience stores, supermarkets, barbershops, restaurants, hospitals, health clubs and more. In the study of the franchise relationship, we will produce a variety of carrier specific services and products collectively referred to as a single store. Single shop is serving the final product that can be produced and that depends on the carrier composed of various elements. As for the franchise, the franchisee is to engage in the process of reproduction service products, first you need to replicate the same by investing in a single store in the market places, and provide services to local consumers through service personnel. Therefore, as for large-scale sales and service products, it is first copied by a single store franchisee offsite market to achieve.

\section{Elements of single-store}

To copy a single-store franchisee, it first needs to know how to copy the method, it is necessary to understand its relation to all constitute a single store. The more simple and easier to store a single copy, the more mature development of single shop and the more easily be replicated. Mature single store constitutes three aspects: First, the tangible evidence of their mature and effective management system; the second is a complete and effective service system; the third is service standards.

1) Tangible evidence. Means services can display or reflect things.

Tangible evidence elements include two parts Services scenes and other tangibles. As shown in Table 1:
Table: 1 elements of tangible evidence

\begin{tabular}{|l|l|l|}
\hline \multicolumn{2}{|c|}{ Services scene } & \multirow{2}{*}{ Other tangibles } \\
\hline \hline External facilities- & Internal facilities & \\
\hline External facilities & External facilities & Business card \\
Mark & Facilities & Stationery \\
Parking & Mark & Bills \\
Surroundings & Layout & Report \\
Surroundings & Air quality / temperature & Staff dress \\
& & Manual \\
& & Web page \\
\hline
\end{tabular}

Tangible evidence is an important part of a single store, the franchisee needs to be replicated in the reproduction of the first tangible evidence, and therefore, a single store operations manual requires all visible elements of a single store system account, including the method value and management of its existence.

2) complete service system.

A service organization complete service system is operating system services, service delivery systems and services together constitute the marketing system. Figure 3:

Service Delivery System

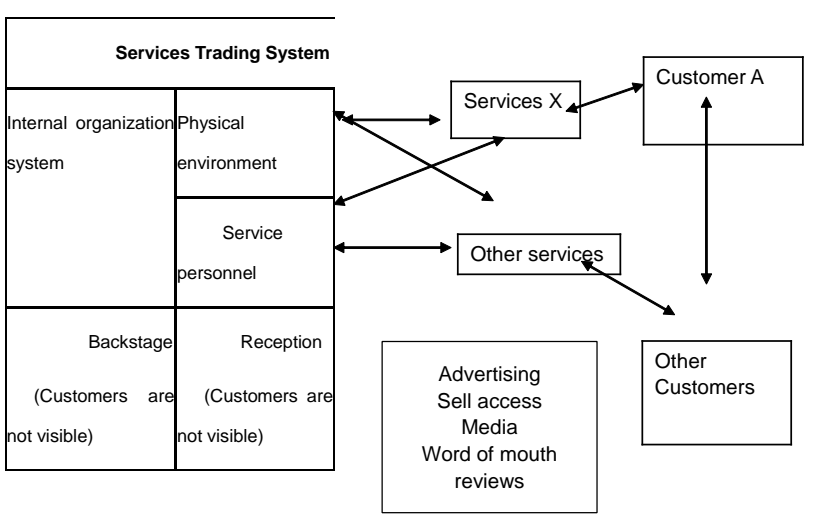

Figure 3 Service System

Service operation system is generally a visible dividing line and is divided into two parts for the foreground and background, as shown above. Reception is visible part of the customer, including service personnel and physical environment. The background is part of the customer, which is not visible, the customer may not even know of its existence, including the internal organizational systems. The production process of a service are: internal organization system resources to process the input form the various elements of service offerings, and through the front desk 
staff and the physical environment in the process of contact with customers in service, for all elements assembly and passed on to customers.

Service delivery system, including the visible part (the physical environment and human) services operating systems and service contact (contact service providers and customers, as well as contact between the customer and the customer) in two parts, pictured above. Two parts of the service delivery system have a direct impact on customer perception of service and customer satisfaction. Service Delivery System provides service product delivered to the customer location, time and manner.

Service marketing system is on behalf of all the possible ways to contact the customer service organization or understand. In addition to service delivery and contact process, other factors also affect customer perception of service, such as advertising and marketing efforts, phone calls and letters, bills, mass media news and reviews, current or former customers of reputation, marketing research, with service personnel or casual contact, such as facilities, these elements together constitute a service delivery system service marketing system.

3) Service standard. Service standards refer to the service organization and management services to guide behavior norms.

Most service organizations have service standards. But many service organizations do not come from the understanding of customer expectations, but their ideas are from the service organization, which is based on the needs and convenience of their own operations, in order to achieve the productivity, efficiency, cost, technical quality of service standards established operational goals, called the company's defined service standards. Service is marketing concepts for service organizations from the expectations and interests of customers, developing customer service standards defined by the company rather than the service standard definition. Customer service standards defined standards can be divided into hard and soft standard types. Hard standard refers to a standard that can be obtained by counting, timing or observation. Soft standard is based on the opinions and feelings, it cannot be directly observed, which must be customers, employees or others to talk to understand, and to be expressed in the form of a standard text.

\section{The contents of a single store operations manual written in principle}

The so-called single-store operations manual is about the franchisor service offerings reproduction method of text, is the franchisor of the detailed process of writing their own constitution and service system service system is how to play a role in the explanation made to guide service products distributors (licensees or franchisees) replication and singlestore operations. According to the above-mentioned singlestore franchise system and its constituent elements of understanding, we can see whether a single store operations manual is written in what form, it should contain the following: a single store tangible evidence, structure, service personnel system workflow service system and service standards. Only in this way, the franchisee is to invest in a foreign market for newly built single-store, and it is the franchisor single copy shop, franchisees can also reproduce in the market places franchisor services products to local consumers.

Tangible evidence section of single store, this section needs to explain elements of service scenarios, the use of other tangible things and tangible evidence, management and maintenance requirements.

The service system components, this section needs to explain the composition of the three-service system that constitutes the system. It includes a description of the specific jobs and staffing the front desk requirements, background jobs and staffing requirements, background support organization and staffing requirements for positions, 
positions and personnel marketing system configuration requirements.

Staff workflow and service standards section, It includes promotional staff works content, methods and techniques, workflow and quality standards for all categories of staff backstage, workflow and service standards front desk staff; this part of the need to explain the contents of the manager's job and the use of management tools.

\section{CONCLUSIONS}

On the basis of the above analysis of elements of our single-store operations manual and nature of the single store, it has proposed content of the preparation of single-store operations manual, which should be contained. And its purpose is to allow the franchisor fully convey its services products to franchisees reproduction method that requires the franchisee to produce goods and services have a complete understanding, which can fully replicate and single-store operators to achieve a successful franchise system operations.

\section{References}

[1] Liang Yanming. Service marketing and management. Guangzhou: Jinan University Press, 2004

[2] Lu E. Pelton, Dave. Stratton, James R. Lemp gold: marketing channels - a relationship management. Zhang Yongqiang, such as translation. Beijing: Mechanical Industry Press, 2004

[3] Zhang Guangling editor. Distribution channel management. Wuhan: Wuhan University Press, 2005

[4] Andrew J. Sherman editor. Franchise Handbook. Li Weihua such as translation. Beijing: Mechanical Industry Press, 2005

[5] Hou Jijian, Tang Aifei. Business Franchise tutorial. Beijing: Mechanical Industry Press, 2005

[6] Adrian Payne (1996), The Essence of Services Marketing, Prentice Hall Inc Europe.

[7] Leonard L.Berry (1996), Disvovering the Soul of Service, Simon \& Schuster Inc.

[8] Christopher H.Lovelock (1996), Marketing Service (Third Edition), Prentice Hall Inc.

[9] Philip Kotler, John Bowen, James Markens (1999), Marketing for Hospitality and Tourism (2nd edition), Prentice Hall Inc. 